\title{
Do health care companies of India fulfil government's new orientation towards CSR activities
} A special consideration towards maternal health

Health care companies of India

\author{
Shashi Lata Yadav \\ Department of Obstetrical and Gynecological Nursing, \\ Institute of Nursing Education, Bambolim, India \\ Babitha Vishwanath \\ Department of Management, \\ Sarojini Naidu Vanita Mahavidyalaya, Hyderabad, India, and \\ Debasis Patnaik \\ Department of Economics, BITS - Pilani (Goa Campus), Sancoale, India
}

\begin{abstract}
Purpose - Corporate social responsibility (CSR) in India includes education, environment, healthcare and rural development. In post-liberalized India, the healthcare sector (services and facilities) has grown in leaps and bounds over last two decades. The purpose of this paper is to reveal and explain the CSR profile of select healthcare companies of India and reveal gaps and scope of healthcare activities with a special consideration towards maternal health.

Design/methodology/approach - Primary data are collected from seven listed companies of Goa state which were willing to participate in the study. In total, 67 companies constituting the Healthcare Sector Index of Standard \& Poor of the Bombay Stock Exchange are considered as secondary source. Data of 59 companies that come within the threshold of Companies Act, 2013, are studied. CSR guidelines (with a turnover of Rs 10bn or a market capitalization of Rs $5 \mathrm{bn}$ or a net profit of Rs $50 \mathrm{~m}$ ) are taken as an initial frame of reference.

Findings - In total, 89.83 per cent of these companies have initiatives related to health care. Structured companies (contribute to the company's overall mission and goals) with CSR policy have committee size varying from three to five directors with an independent director. During 2016-2017, they were mandated to spend Rs 4.2613bn out of which only 74.59 per cent was spent. Geographical spread of CSR initiatives is skewed, with majority of companies focussing on the states of Maharashtra and Gujarat, whereas the states of Odisha and North-Eastern being neglected. The focus areas of CSR are education, healthcare and rural development. The variation of MMR in different states of India is an indicator for corporate as to which state needs more attention. The corporate sector in India needs to focus on SDG3 target of MMR and move towards a newer dimension and direction.

Originality/value - The originality of this paper lies in the recognition of the initiative of Government of India of weaning out CSR activities outside the purview of business sense and towards instilling a social sense in company behaviour. This is a dimensional and directional change in the evolution of CSR practices in companies and countries. To this end, 59 healthcare sector companies under the threshold of Companies Act 2013 were studied and results were outlined.
\end{abstract}

Keywords Corporate social responsibility, Companies act, Healthcare sector, Maternal health,

Maternal mortality

Paper type Research paper

(C) Shashi Lata Yadav, Debasis Patnaik and Babitha Vishwanath. Published in Journal of Health Research. Published by Emerald Publishing Limited. This article is published under the Creative Commons Attribution (CC BY 4.0) licence. Anyone may reproduce, distribute, translate and create derivative works of this article (for both commercial and non-commercial purposes), subject to full attribution to the original publication and authors. The full terms of this licence may be seen at http:// creativecommons.org/licences/by/4.0/legalcode

Received 8 February 2019 Accepted 24 June 2019 
JHR
34,1

32

Maternal mortality

\section{Introduction}

In terms of Marquina[1] classification of stages of growth in corporate social responsibility (CSR), Indian CSR needs to move towards a greater and detailed developmental stage. According to Moon[2], CSR should contribute to the sustainability agenda. Maternal healthcare (WHO)[3] is still primitively practised across large sections of Indian society. Maternal health refers to health of women during pregnancy, childbirth and postpartum period. Maternal health, as addressed by Millennium Development Goals and Sustainable Development Goals, is shown in Table I.

WHO[4] stated that, women in low-income countries live lesser years. As per WHO[5] 2013, 289,000 women expired during pregnancy and childbirth, due to the lack of access to skilled routine care and emergency care. According to National Health Mission[6], services to pregnant women include early antenatal registration, consumption of iron folic acid tablets as prophylaxis, regular antenatal check-ups, monitoring of blood pressure/foetal heart sound/foetal movement count, tetanus toxoid immunization, timely detection of high-risk antenatal cases and their timely referral, delivery in safe and hygienic environment by skilled birth attendant, timely referral in case of obstetric emergency for management of haemorrhage with blood transfusions, availability of caesarean section facility and minimum three postnatal visits and spacing of at least three years between births. Initiatives towards problem mitigation are undertaken by various institutions, like international bodies, domestic governments and business entities. Availability of a greater number of health services early in pregnancy would improve maternal health and decrease MMR[7] in the Gujarat State of India.

According to the Millennium Development Goals[8] in Sub-Saharan Africa and Southern Asia, more than 500,000 women die from treatable or preventable complications of pregnancy and childbirth. In Sub-Saharan Africa, a woman's risk of dying from such complications over the course of her lifetime is 1 in 16 , compared to 1 in 3,800 in the developed countries. United Nations International Children's Emergency Fund[9] reported that over a decade, disparity in closing the gap in antenatal care between urban and rural women remains constant. From lack of antenatal care and behaviour towards birth control, there are problems in the way even the developed economies approaches pregnancy, childbirth and the postpartum period.

Agrawal[10] stated that in the USA, mothers suffer complications during pregnancy or childbirth resulting in high maternal morality and maternal morbidity. The State of the World's Mothers in the USA[11] reveals that 1 in 1,800 women faces the risk of maternal death. Dockterman[12] stated that the USA ranked number 42 on children's well-being and number 61 on maternal health, projecting the fact that women are more than ten times as likely to die from a cause related to pregnancy vis-à-vis Belarus, Poland and Austria.

\begin{tabular}{|c|c|c|c|c|c|c|}
\hline $\begin{array}{l}\text { Serial } \\
\text { No. }\end{array}$ & Year & $\begin{array}{l}\text { MMR per } \\
100,000 \\
\text { live births }^{\mathrm{a}}\end{array}$ & $\begin{array}{l}\text { Maternal } \\
\text { death } \\
\text { (numbers) }\end{array}$ & $\begin{array}{c}\text { AIDS-related } \\
\text { indirect maternal } \\
\text { deaths }\end{array}$ & $\begin{array}{l}\text { Live } \\
\text { births } \\
\text { ('000s) }\end{array}$ & $\begin{array}{l}\text { Proportion of maternal deaths } \\
\text { among deaths of female } \\
\text { reproductive age (PM \%) }\end{array}$ \\
\hline 1 & 1990 & 556 [445-685] & 152,000 & 5 & 27,430 & 19.7 \\
\hline 2 & 1995 & $471[396-560]$ & 130,000 & 53 & 27,671 & 16.4 \\
\hline 3 & 2000 & 374 [324-437] & 104,000 & 250 & 27,884 & 13.0 \\
\hline 4 & 2005 & 280 [240-324] & 77,000 & 520 & 27,634 & 9.8 \\
\hline 5 & 2010 & 215 [183-255] & 57,000 & 420 & 26,566 & 7.6 \\
\hline 6 & 2015 & 174 [139-217] & 45,000 & 280 & 25,794 & 6.2 \\
\hline
\end{tabular}

Notes: ${ }^{a}$ MMR and PM are calculated for women between 15 and 49 years; 'blive birth data from World Population Prospects: the 2015 Revision New York, Population Division, Department of Economic and Social Affairs, United Nations Secretariat, 2015 


\section{Maternal health and international initiatives}

Over 90 per cent of these deaths can be prevented if women in developing regions had access to sufficient diet, basic literacy and health services, safe water and sanitation facilities during pregnancy and childbirth says MDG Monitor[13].

Improving maternal health was cited as the fifth MDG. The goal had two targets: to reduce the MMR by 75 per cent and to achieve universal access to reproductive health by 2015. The set targets were not achieved fully though MMR dropped from 380 in 1990 to 210 in 2013 indicating a 45 per cent decline. Similarly, global births attended by skilled health personnel increased to 71 per cent in 2014 from 59 per cent in 1990 indicating 12 per cent difference between the targeted and the achieved. Thus, Sustainable Development Goal 3's target was moderate - to reduce global MMR to less than 70 per 100,000 births by 2030 as disclosed by MDG 5[14].

\section{India's maternal health status}

Mazumdar[15] explained that India is confronted with a host of challenges such as poverty, malnutrition and high disease burden. Huber[16] informed that more than 40 per cent of women in India are underweight during pregnancy. As per Woodrow Wilson School of Public and International affairs study published by Princeton University, on an average, Indian women gain only 15 pounds throughout pregnancy - just half the recommended weight. In Sub-Saharan Africa, only 16.5 per cent of women are underweight before pregnancy. This may suggest why Indian children are shorter and smaller than African children despite the fact that former are healthier.

The Government of India (GOI) has initiated various schemes for women under the National Rural Health Mission (NRHM).This includes Janani Suraksha Yojana which is an intervention scheme for safe motherhood. Integrated Child Development Services Programme aimed at providing services to preschool children to ensure growth and development of children in rural, tribal and slum areas. Kishori Shakti Yojana brings about positive changes in the lives of adolescent girl by providing access to health care centres/anganwadi centres every six months and creating awareness about various disease conditions. Nutrition Programme for Adolescent Girls in the context of income disparities in India is looked into. Accessibility/affordability to quality health care and ethical practices rest at the heart of a healthcare company's CSR strategy[17].

\section{Strength and weakness of healthcare in India}

Maternal health outcomes towards reducing MMR are gaining momentum. Government incentives are a motivating factor for increased institutional deliveries[18].

The use of telemedicine through public- private partnership is increasing in number[19]. The telemedicine software system by the Centre has assisted the School of Tropical Medicine, Kolkata, and two district hospitals in India. Indian Space Research Organization's telemedicine has connected islands of Andaman and Nicobar/Lakshadweep, Kargil and Leh, and a few others to government rural and district hospitals of Odisha[20].

The weaknesses in the healthcare system include underfunding of current cost, infrastructure mismatch, deficiency of human resources in health, absenteeism among doctors, hiring contractual staff, deficiency in training, lack of outreach, overcrowding of hospitals, lack of purchasing power by the client, public hospitals' inaccessibility to common man, less of holistic approach and more focus on curative than preventive functions[21].

The National Institution for Transforming India Aayog[22] has announced that the Indian Government initiatives like National Health Mission and NRHM have been instrumental in enhancing the health of its citizens. India's MMR has declined from 570 in 1990 to 230 in 2012. In 2011-2013, India's MMR stood at 167.
Health care companies of India 
JHR

34,1

34

As per Maternal Mortality Estimation Inter-Agency Group India, World Bank Group[23] estimates that the MMR in India (2007-2010) has declined from 254 per 100,000 live-births in 2004-2007 to 212 per 100,000 live-births in 2007-2010. Maternal mortality in India 2014-2016 has shown a further decline in MMR, i.e., 130 per 100,000 live-births as reported in SRS[24]. Data on All India MMR during the last 15 years are presented in Table II.

NRHM[25] communicated that improvement could be due to key government interventions in the promotion of institutional deliveries through Janani Shishu Suraksha Karyakram launched in 2011, to provide free maternity services to pregnant women delivering in public health institutions.

In the context of institutional reforms, company level CSR function is being stressed by the GOI to generate better outcomes and mitigate suffering of women advancing to fulfilment of aims in MDG and SDG. This paper aims to achieve following objectives:

(1) to explain CSR profile of select healthcare companies of India;

(2) to assess the geographical spread of companies and implementation of health care mandate; and

(3) to reveal gaps and scope of healthcare activities in the Indian context.

\section{Methodology}

To assess the CSR agenda of healthcare companies in general and more specifically in the area of maternal health, primary data were collected from six pharmaceuticals and one non-pharmaceutical company of Goa state that were willing to participate in the study.

Ethical clearance was obtained from the companies and the confidentiality clause of not disclosing names of companies was adhered. However, all companies surveyed were listed companies with high market cap category so that comparability with companies selected from secondary source was maintained.

Secondary data from 67 companies constituting the Healthcare Sector Index of Standard \& Poor of the Bombay Stock Exchange were considered. Out of 67 companies, data on 59 companies that come within the threshold of Companies Act, 2013, were studied. CSR guidelines (with a turnover of Rs $10 \mathrm{bn} /$ more or a market capitalization of Rs $5 \mathrm{bn}$ or a net profit of Rs $50 \mathrm{~m}$ or more) presented in Table III are taken as an initial frame of reference. The annual reports of the selected sample companies 2016-2017 are considered to collect data related to - CSR Policy, CSR Committee-constitution and size, Independent directors on Committee, Committee meetings held during the year, amount liable to be spent during the year 2016-2017, actual amount spent during the year, CSR activities undertaken, geographical spread of CSR activities and initiatives adopted by the companies, alongside the data on respective implementing agencies.

\section{CSR and government}

Lozano et al.[26] stated that CSR has become a priority issue on governments' agenda for addressing the challenge of sustainability say's Bell[27].

Gatti et al.[28] admitted that India legislated CSR through Section 135 of Companies Act, 2013. As per Moon and Vogel[29], the GOI opted to regulate CSR. In contrast to many

Table II.

MMR in India from 2004 to 2016

\begin{tabular}{lcc}
\hline Serial No. & Year & MMR in India \\
\hline 1 & $2004-2007$ & 254 \\
2 & $2007-2010$ & 212 \\
3 & $2010-2013$ & 178 \\
4 & $2011-2014$ & 167 \\
5 & $2014-2016$ & 130
\end{tabular}




\begin{tabular}{|c|c|c|c|c|}
\hline Serial No. & Company & Serial No. & Company & Health care \\
\hline 1 & Aarti Drugs Ltd & 31 & Laurus Labs Ltd & India \\
\hline 2 & Abbott India Ltd & 32 & Lupin Ltd & \\
\hline 3 & Ajanta Pharma Ltd & 33 & Mangalam Drugs and Organics Ltd & \\
\hline 4 & Alembic Ltd & 34 & Marksans Pharma Ltd & \\
\hline 5 & Alembic Pharmaceuticals Ltd & 35 & Morepen Laboratories Ltd & \\
\hline 6 & Alkem Laboratories Ltd & 36 & Narayana Hrudayalaya Ltd & 35 \\
\hline 7 & Apollo Hospitals Enterprise Ltd & 37 & Natco Pharma Ltd & \\
\hline 8 & AstraZeneca Pharm India & 38 & Nectar Lifesciences Ltd & \\
\hline 9 & Aurobindo Pharma Ltd & 39 & Neuland Laboratories Ltd & \\
\hline 10 & Biocon Ltd & 40 & Novartis India Ltd & \\
\hline 11 & Bliss GVS Pharma Ltd & 41 & Opto Circuits India Ltd & \\
\hline 12 & Cadila Healthcare Ltd & 42 & Pfizer Ltd (India) & \\
\hline 13 & Caplin Point Laboratories Ltd & 43 & Piramal Enterprises Ltd & \\
\hline 14 & Cipla Ltd/India & 44 & Poly Medicure Ltd & \\
\hline 15 & Divi’s Laboratories Ltd & 45 & RPG Life Sciences Ltd & \\
\hline 16 & Dr Reddy's Laboratories Ltd & 46 & Sanofi India Ltd & \\
\hline 17 & Dr Lal PathLabs Ltd & 47 & Shalby Ltd & \\
\hline 18 & Eris Lifesciences Ltd & 48 & Shilpa Medicare Ltd & \\
\hline 19 & FDC Ltd & 49 & SMS Pharmaceuticals Ltd & \\
\hline 20 & Fortis Healthcare Ltd & 50 & Sun Pharma Advanced Research Co Ltd & \\
\hline 21 & GlaxoSmithKline Pharmaceuticals Ltd & 51 & Sun Pharmaceutical Industries Ltd & \\
\hline 22 & Glenmark Pharmaceuticals Ltd & 52 & Suven Life Sciences Ltd & \\
\hline 23 & Granules India Ltd & 53 & Syngene International Ltd & \\
\hline 24 & GuficBioSciences Ltd & 54 & Thyrocare Technologies Ltd & \\
\hline 25 & HESTER PHARM & 55 & Torrent Pharmaceuticals Ltd & Table III. \\
\hline 26 & Indoco Remedies Ltd & 56 & Unichem Laboratories Ltd & Sample companies of \\
\hline 27 & Indraprastha Medical Corp. Ltd & 57 & Vimta Labs Ltd & healthcare sector \\
\hline 28 & Ipca Laboratories Ltd & 58 & Vivimed Labs Ltd & constituting \\
\hline 29 & J.B. Chemicals \& Pharmaceuticals Ltd & 59 & Wockhardt Ltd & healthcare sector \\
\hline 30 & Jubilant Life Sciences Ltd & & & index on BSE \\
\hline
\end{tabular}

governments that have chosen to draw businesses further into governance issues without actually mandating behaviour, GOI has mandated a class of companies, but without specifying any penalties for non-compliance of the same. The initiative of GOI has been more in the direction of weaning out CSR activities outside the purview of business sense and towards instilling a social sense in company behaviour. Section 135 of Indian Companies Act, 2013 directs companies to focus on how much to spend, where to spend, what to report and to create sub-systems in companies for implementation of CSR policies. Schedule VII of Companies Act suggests CSR focus areas for companies is towards reducing child mortality and improving maternal health[30].

\section{CSR and healthcare sector in India}

Vishwanath[31] revealed that CSR is understood and implemented differently across companies/sectors/industries and countries. In post-liberalized India, healthcare companies are traded on Indian stock exchanges in India and are listed in multiple stock exchanges abroad.

The TATA group has been providing assistance to non-government organizations working in the areas of education, health care and employment, and Birla Group has developed an exemplary village in education, health care and family welfare. The Infosys Science Foundation has taken initiative in assisting health care, culture and rural development programmes. Mahindra \& Mahindra launched Nanhi Kali programme, which supports education of over 75,000 underprivileged girls. The company shows focus towards environment, health care, sports and culture. In view of governmental limitations, the 
JHR

34,1

corporate sector should contribute more towards public health[32]. The Reserve Bank of India suggested that banks should pay special attention towards the integration of social and environmental concerns in their business operations[33].

Ranbaxy Sanjeevan Swasthya Sewa focusses on early detection of commonly found cancers of cervix, breast and oral cavity. The programme covers a total population of about 4.50 lakh in 180 villages in Punjab[34]. Distance Healthcare Advancement (DISHA) is a telemedicine initiative providing affordable health care through mobile vans to poor communities and also organizes monthly camps for expecting mothers[35].

Cipla Foundation set up in 2010 is also working on running mobile vans and maternal health. Fortis hospital's focus is on mother and child care, education, environment and capacity building. Aanchal is the mother-centric programme to improve community and societal health[36].

As per the Companies Act, 2013, all companies having a turnover of Rs 10bn or more, or a net worth of Rs 5bn or more or a net profit of Rs $50 \mathrm{~m}$ or more during any financial year are required to constitute a CSR Committee of Board of Directors comprising three or more directors with at least one independent director[37]. All these companies are required to spend at least 2 per cent of their immediately preceding three financial years' average net profits on CSR-related activities. The Economic Times disclosed that India's top 200 companies (in terms of market capitalization) spent around Rs $13.69 \mathrm{bn}$ on healthcare and wellness. About 24 per cent of the total amount is spent on healthcare especially to conduct health camps and building hospitals or donating to hospitals for upkeep/maintenance of facilities as stated by Rana and Mazumdar[38].

The CSR activities[39] mentioned in the Companies Act 2013 are towards Eradicating extreme hunger and poverty, promoting gender equality and empowering women, Reducing child mortality and improving maternal health, Combating human immunodeficiency virus, acquired immune deficiency syndrome malaria and other diseases, Ensuring environmental sustainability, Employment enhancing vocational skills and Social business projects. Contribution to the Prime Minister's National Relief Fund or any other fund set up by the Central Government or the State Governments for socio-economic development and relief, and funds for the welfare of the Scheduled Castes, the Scheduled Tribes, other backward classes, minorities and women is also mentioned. Other matters may also be prescribed.

\section{Results from secondary data}

CSR reports of -59 sample companies are studied to assess CSR policy, nature/composition of committee and amounts spent.

All the sample companies have formulated CSR policy and obtained approval from the Board of Directors (committee) according to Companies Act, 2013 guidelines. CSR Committee size varies from three to five directors. The percentage of the companies with 3 members is 59.3, whereas 33.9 per cent have four directors and rest 6.8 per cent have five directors. All the sample 59 companies are following the Companies Act guideline of having at least one independent director in the CSR Committee. Among the 59 companies, 59.3 per cent have one independent director on the Committee, whereas 32.2 per cent have two independent directors and 8.5 per cent have three independent directors on the Committee during the year 2016-2017. Among the selected -59 healthcare sector companies, four of them had negative net profit and hence were not obliged to spend for CSR activities. In total, -55 companies were expected to spend Rs 4.2613bn but only Rs 3.1787bn was spent in 2016-2017 indicating that the norm of spending two per cent on CSR activities is not being followed by all. Only 74.6 per cent of the funds have been spent. Three companies spent Rs $108.7 \mathrm{~m}$ for the same. In total, 12 of the sample companies have spent more than the required amount during the year. Although the amount sanctioned was Rs 66.25 crores (for committee size -5), yet an amount of only Rs 40.55 crores was spent for the same (Table IV). 
Discussion

Experience suggests that a closer monitoring by government would reduce gaps in spending between the targeted and the actual. There is also a need for clearer focus on CSR funds being spent on Maternal Health factors/items through community administrative agencies.

\section{Geographical spread of CSR projects}

Dey[40] revealed that during 2014-16, Kerala emerged as the best state in providing public healthcare with an MMR rate of 46 followed by Maharashtra at 61 and Tamil Nadu at 66 . The worst performing states were Assam (237), UP/Uttarakhand (207) and Rajasthan (199). CSR projects of healthcare sector companies were varying across the country during 2016-2017. Three states had no specific CSR projects from any of the selected -59 companies. In total, 11 companies mentioned that some of their CSR projects were undertaken across India, whereas 5 companies mentioned that some of their CSR projects are carried on in the local areas. One company's CSR activities were undertaken in North Capital Region area, whereas one extended it to Nepal. Out of the sample companies belonging to healthcare sector, 93 per cent of them focussed on healthcare. *The second most area attracting CSR projects are in the fields of education** (i.e. 76 per cent). **Environment,***Rural Development,**** and Drinking water*****also receive substantial attention. The details of CSR activities of the selected companies are presented in Table V.

\section{On types of CSR activities undertaken by companies'}

Table V shows relatively lesser focus on health care, gender equality and empowerment of women. However, CSR activities on all areas mentioned provide for a sound developmental ecology for efficient functioning of women.

\section{Implementation agencies}

CSR activities are undertaken with the help of implementing agencies. In total, 18 of the sample companies have established their own foundations, and the latter implements

\begin{tabular}{llcccc}
\hline Serial No. & Particulars & Minimum & Maximum & Average & SD \\
\hline 1 & Committee size & 3 & 5.00 & 3.00 & 0.63 \\
2 & Independent directors & 1 & 3.00 & 1.00 & 0.65 \\
3 & Committee meetings & 0 & 6.00 & 2.00 & 1.35 \\
4 & Amount to be spent (Rs in crore) & 0 & 66.25 & 7.75 & 13.4 \\
5 & Actual amount spent (Rs in crore) & 0 & 40.55 & 5.89 & 8.81
\end{tabular}

Health care companies of India

\begin{tabular}{|c|c|c|c|c|c|c|}
\hline $\begin{array}{l}\text { Serial } \\
\text { No. }\end{array}$ & CSR project area & $\begin{array}{c}\text { No. of } \\
\text { companies }\end{array}$ & $\begin{array}{c}\text { Serial } \\
\text { No. }\end{array}$ & CSR project area & $\begin{array}{c}\text { No. of } \\
\text { companies }\end{array}$ & \\
\hline 1 & Art and Culture & 3 & 12 & Gender Equality & 4 & \\
\hline 2 & Capacity Building & 2 & 13 & Health care & $55^{*}$ & \\
\hline 3 & Community Development & 3 & 14 & Leadership Building & 2 & \\
\hline 4 & Disability & 2 & 15 & Livelihood & 7 & \\
\hline 5 & Disaster Response & 4 & 16 & Old Age Homes & 3 & \\
\hline 6 & Drinking Water & $10 * * * * *$ & 17 & Rural Development & $13 * * * *$ & \\
\hline 7 & Education & $45^{* *}$ & 18 & Skill Development & 6 & \\
\hline 8 & Empowerment of Women & 1 & 19 & Social Welfare & 2 & \\
\hline 9 & Environment & $15^{* * * *}$ & 20 & Socio-Economic Activities & 4 & Table V. \\
\hline 10 & $\begin{array}{l}\text { Eradicating Hunger } \\
\text { Poverty/Malnutrition }\end{array}$ & 6 & 21 & Sports & 7 & $\begin{array}{l}\text { CSR activities } \\
\text { undertaken by }\end{array}$ \\
\hline 11 & Food & 2 & 22 & Vocational Skills & 6 & companies \\
\hline
\end{tabular}


JHR

34,1

38

the CSR projects. The number of companies opting for NGOs is less in comparison to other agencies. In total, -53 companies are opting for different kinds of agencies like academic institutions, associations, chambers of commerce and industry, charitable trusts, external partners, foundations, hospitals, local authority - panchayat, rotary club, samities, societies, trusts and universities to deliver services.

\section{A focus on primary data}

Selected companies of Goa State. Table VI study on six pharmaceutical and one non-pharmaceutical company in Goa revealed that all the seven companies (100 per cent) had undertaken CSR activities related to promotion of education. While majority, i.e. 71.42 per cent were involved in ensuring environmental sustainability and enhancing vocational skills, respectively, only 55.14 per cent had undertaken CSR activity towards social business projects and contribution to the Prime Minister's National Relief Fund or any other fund set up by the government/state (Table VII).

\section{Results with regard to primary data}

With regard to maternal health, Table VII indicates that only 1-2 per cent companies have taken up activities related to immunization, distribution of tablets (deworming/iron supplementation), health insurance, awareness about adolescent health, provision for prenatal diagnostic tests/developing and linking home- and community-based services. But out of seven companies not a single company has any activity related to antenatal check-ups for the mother, distribution of sanitary pads for postnatal mothers and distribution of new-born clothes and provisions undertaken/activities related to maternal subsidies through vouchers.

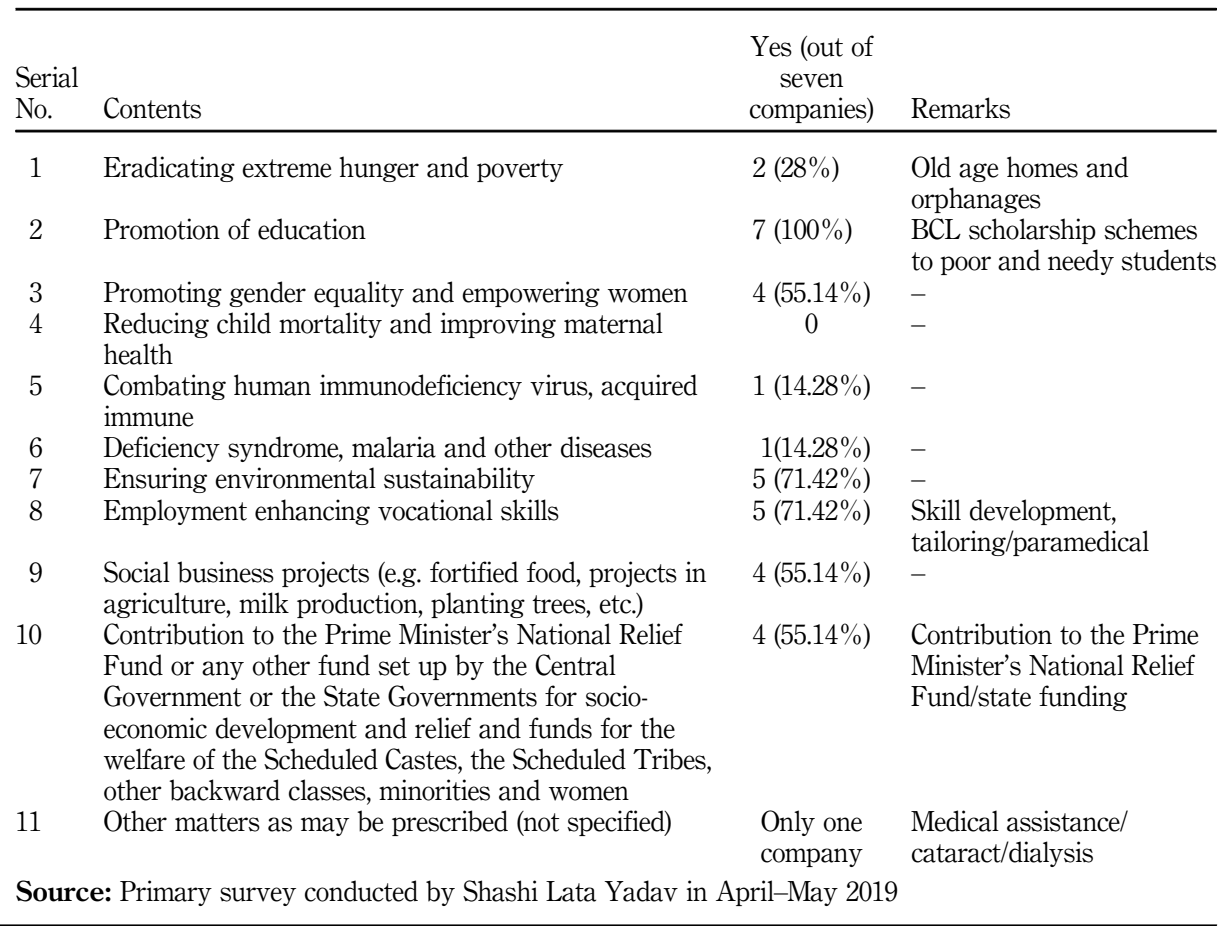

Table VI.

CSR activities undertaken by companies in Goa

Source: Primary survey conducted by Shashi Lata Yadav in April-May 2019 


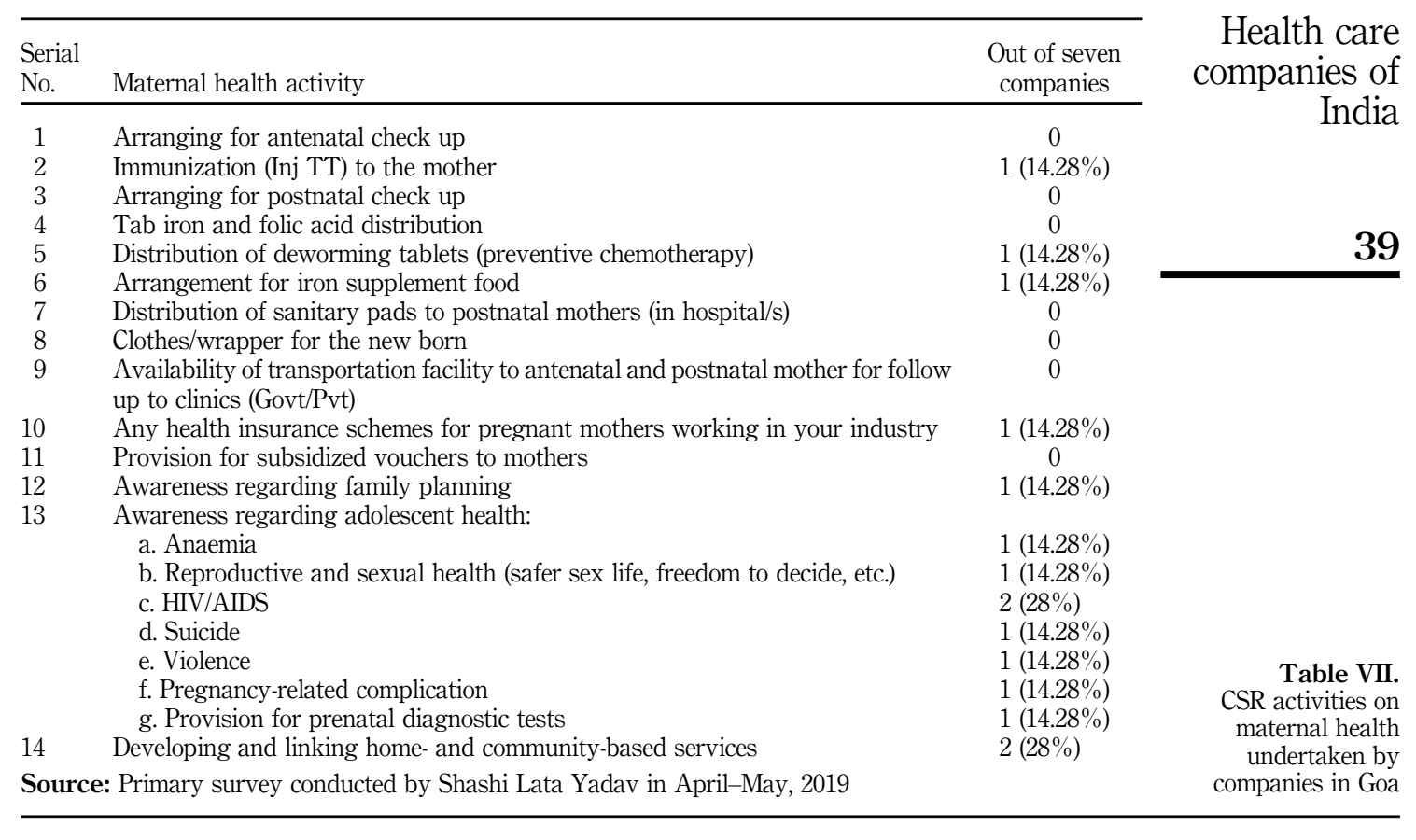

\section{Discussion}

No details were given by the participants in relation to approximate average yearly fund used by the respective companies for CSR activity related to maternal health only.

\section{Conclusion}

Based on the findings of the study, it is concluded that the healthcare sector in India has abided by Schedule 135 of the Companies Act 2013 CSR guidelines. Individual companies' framed policies and created a sub-system of CSR Committee with independent directors to plan CSR initiatives and to ensure that a CSR budget (2 per cent of three years average net profit) is spent. The size of the committee is varying and geographical spread of CSR initiatives is skewed, with majority companies focussing on Maharashtra and Gujarat states. The focus areas of CSR are on education, healthcare and rural development. There is a need to look at the under-developed and remote states like Odisha and North-Eastern states.

The healthcare sector companies in India should spend money/resources for community development with special emphasis on maternal health, in terms of antenatal/postnatal check-up, focus on adolescent health, awareness on female suicide/violence and provision for prenatal diagnostic tests thus helping stakeholders achieving accessibility to healthcare facilities. Variation in MMR in different states of India is an indicator for corporates, as to which state need more attention. Focussing on those states would ensure that the SDG 3 target of MMR (70) is achieved in the states. The government need to be motivated to collaborate with corporates, NGOs and other sectors of societies and play a significant role in building quality health delivery system in. Moreover, it has scope and opportunity to offer a "one-stop" location that can integrate various types of maternal health services to the deserving/needy people in the community. Failure to invest in maternal health undermines national economic growth and development. 
JHR

34,1

\section{References}

1. Marquina P. Measuring the impact of corporate social responsibility on consumer behaviour: the case of Peruvian consumers. Miami, FL: Florida International University; 2007.

2. Moon J. Government as a driver of corporate social responsibility. Nottingham: International Centre for Corporate Social Responsibility, University of Nottingham; 2004.

3. World Health Organization [WHO]. Trends in maternal mortality 1990 to 2013. Geneva: WHO; 2014.

4. World Health Organization [WHO]. Women and health: today's evidence tomorrow's Agenda. Geneva: WHO; 2009.

5. World Health Organization-South-East Asia [WHO-SEARO]. Maternal mortality: fact sheet no. 348 (on 11 May 2014). New Delhi: WHO-SEARO; 2014.

6. National Health Mission, Department Government of Gujarat, India. State health society, health and family welfare-e-resource. Gujarat: Department of Government of Gujarat; 2018.

7. Mavalankar DV, Vora KS, Ramani KV, Raman P, Sharma B, Upadhyaya M. Maternal health in Gujarat, India: a case study journal of health, population and nutrition. J Health Popul Nutr. 2009 Apr; 27(2): 235-48.

8. United Nations [UN]. The millennium development goals report 2007. New York, NY: UN; 2007.

9. UNICEF. Maternal and new born health. New York, NY: UNICEF; 2016.

10. Agrawal P. Maternal mortality and morbidity in the United States of America. Bull World Health Organ. 2015 Mar; 93(3): 135

11. Save the Children. Times of crisis, for our future: the urban disadvantage state of the world's mothers. US: Save the Children; 2015.

12. Dockterman E. US ranks worst developed country for maternal health; 2015 [cited 2017 Dec]. Available from: https://time.com/3847755/mothers-children-health-save-the-children-report

13. Millennium Development Goals. Improve maternal health; 2016. [cited 2017 Dec]. Available from: www.mdgmonitor.org/mdg-5-improve-maternal-health

14. Millennium Development Goals. Millennium development goal five: improve maternal health: the millennium development goals seek to solve some of the world's biggest problems by 2015; 2011. [cited 2017 Dec]. Available from: www.theguardian.com/globaldevelopment/2011/aug/05/ millennium-development-goal-maternal-health

15. Mazumdar SK. Leveraging affordable innovation to tackle India's healthcare challenge. IIMB Management Review. 2018; 30(1): 37-50.

16. Huber BR. Maternal health in India much worse than previously thought Woodrow Wilson School of Public and International Affairs; 2015. [cited 2017 Dec]. Available from: https://wws.princeton. edu/news-and-events/news/item/maternal-health-india-much-worse-previously-thought

17. Desai PS, Chandawarkar MR. Aligning CSR activities of health care sector to developmental needs of India. J Pharm Sci \& Res. 2016; 8(9): 1-9.

18. Srivastava A, Bhattacharyya S, Clar C, Avan BI. Evolution of quality in maternal health in India: lessons and priorities. Int J Medicine \& Pub Health. 2014; 4(1): 33-9.

19. Ramani KV, Mavalankar D. Health system in India: opportunities and challenges for improvements. J Health Organ Manag. 2006; 20(6): 560-72.

20. Dasgupta A, Deb S. Telemedicine: a new horizon in public health in India. Indian J Community Med. 2008 Jan; 33(1): 3-8.

21. Bajpai V. The challenges confronting public hospitals in India, their origin, and possible solutions. Advances in Pub Health. 2014; 1-27. Available from: http://dx.doi.org/10.1155/2014/898502

22. National Institution for Transforming [NITI] Aayog, India. Maternal mortality ratio (MMR) (per 100000 live births); 2018. [cited 2017 Dec]. Available from: http:/niti.gov.in/content/maternalmortality-ratio-mmr-100000-live-births 
23. WHO, UNICEF, UNFPA, World Bank Group, and United Nations Population Division. Trends in maternal mortality: 1990 to 2015. Geneva: WHO; 2016.

24. Office of Registrar General, India. Special bulletin on maternal mortality in India 2014-16. New Delhi: Vital Statistics Division; 2018.

25. Maternal Health Division, Ministry of Health and Family Welfare, Government of India. National rural health mission: guidelines for Janani Shishu Suraksha Karyakram (JSSS). New Delhi: Division; 2011.

26. Lozano AL, Lozana JM, Ysa T. Public policies on corporate social responsibility: the role of governments in Europe. J Business Ethics. 2007; 74(4): 391-470.

27. Bell VJD. The role of government in advancing corporate sustainability: background paper. Vancouver: The Sustainable Enterprise Academy, York University; 2002. p. 31.

28. Gatti L, Vishwanath B, Seele P, Cottier B. Are we moving beyond voluntary CSR? Exploring theoretical and managerial implications of mandatory CSR resulting from the new Indian Companies Act. J Business Ethics. 2018 Jan; 1-33.

29. Moon J,Vogel D. Corporate social responsibility, government and civil society. Oxford: Oxford University Press; 2008. p. 303-23.

30. Grant Thornton International Ltd. Implications of Companies Act, 2013: corporate social responsibility. New Delhi: Grant Thornton; 2013. p. 1-6.

31. Vishwanath B. Power generating sector: softening the impact. Jatana R, Crowther D (Eds). Corporate social responsibility - theory and practice with case studies. New Delhi: Deep \& Deep Publications; 2007. p. 444-53.

32. Nishandar VV. Corporate social responsibility - the way ahead. Bus Manag Rev. 2015; 5(4): 127-31.

33. Sharma N. CSR practices and CSR reporting in Indian banking sector. IJAEBM. 2016; 1(2): 58-66.

34. Motha CSL, Nalini R, Alamelu R, Amudha R. The moral calculus of pharma company's in India. Asian J Pharm Clin Res. 2016; 9(2): 30-3.

35. Ministry of Health and Family Welfare, Government of India. Digital information security in healthcare act. New Delhi: Ministry; 2017. p. 1-33.

36. Saucepan Media Private Limited. CSR of healthcare companies: health (care) is wealth. New Delhi: Saucepan Media Private Limited; 2018.

37. Bryant D. India releases CSR policy rules for Companies Act 2013. [cited 2017 Dec]. Available from: www.lexology.com/library/detail.aspx?g=c8fed18d-68e8-49ba-b3ee-acd1775a10d4

38. Rana N, Majmudar U. How can help improve healthcare, 2017. The Economic Time Blog, 17, March [cited 2017 Dec]. Available from: https://economictimes.indiatimes.com/blogs/ResponsibleFuture/ sustainability-and-csr-trends-for-india-in-2017/

39. Gahlot S. Corporate social responsibility: current scenario. Res J Management Sci. 2013; 2(12): 12-14.

40. Dey S. Maternal mortality drops to 130, Kerala top, big improvement in backyard states, 2018, 7 Jun. The Times of India. [cited 2018 Jun]. Available from: https://timesofindia.indiatimes.com/india/ maternal-mortality-drops-to-130-kerala-top-big-improvement-in-backward-states/articleshow/ 64486279.cms

\section{Corresponding author}

Shashi Lata Yadav can be contacted at: sshashi_63@yahoo.com

For instructions on how to order reprints of this article, please visit our website: 